\title{
Decision-making among patients and their family in ALS care: A review
}

Accepted for publication in Amyotrophic Lateral Sclerosis and Frontotemporal Degeneration, 2017

Authors' version pre-publication

\section{Authors}

Geraldine Foley PhD

Assistant Professor (Occupational Therapy),

School of Medicine

Trinity College Dublin

Trinity Centre for Health Sciences, James's Street, Dublin 8

Ireland

Email: foleyg3@tcd.ie

Tel: +353-1-8963215

Geralyn Hynes PhD

Associate Professor in Palliative Care \& Director of Research

School of Nursing and Midwifery

Trinity College Dublin

D’Olier Street, Dublin 2

Ireland

Email: hynesg2@tcd.ie

Tel: +353-1-8964081 


\section{Abstract}

Objectives: Practice guidelines in ALS care emphasise the role of the patient and their family in the decision-making process. We aimed to examine the ALS patient/family relationship in the decisionmaking process and to ascertain how patients and their family can shape one another's decisions pertaining to care.

Methods: We conducted a review of peer-reviewed empirical research, published in full and in English between January 2007 and January 2017, relating to care decision-making among ALS patients and their family. Database sources included: Medline; CINAHL; AMED; PsycINFO; PsycARTICLES; and Social Sciences Full Text. A narrative synthesis was undertaken.

Results: Forty-seven studies from the empirical literature were extracted. The family viewpoint was captured primarily from family members with direct care-giving duties. Patients' cognitive status was not routinely assessed. The findings revealed that the decision-making process in ALS care can be contoured by patients' and family caregivers' perceived responsibilities to one another and to the wider family.

Conclusions: Greater attention to family member roles beyond the primary caregiver role is needed. Strategies that integrate cognitively-impaired patients into the family decision-making process require investigation. Identification of the domains in which ALS patients and their family members support one another in the decision-making process could facilitate the development of patient/family decisionmaking tools in ALS care.

\section{Key words}

Decision making, supportive care, care preferences, family processes 


\section{Introduction}

Guidelines for best practice in ALS care emphasise the role of the patient and their family in the decision-making process (1). ALS patients and their family engage with a diverse range of services, in general and specialist care (2). The progressive nature of ALS means that patients and their family confront complex decisions about care from diagnosis to bereavement $(3,4)$. Integration of family into the decision-making process can impact on how patients make decisions about care (5). In ALS, we know that family caregivers encounter carer burden (6) and that patients depend on family for care $(7,8)$. However, little is known about how ALS patients and their family interrelate in decision-making processes pertaining to care.

Few systematic reviews have focused on the relationship between terminally-ill patients and their family in the decision-making process (9). In this review, we aimed to examine the ALS patient/family relationship in the decision-making process and to ascertain how ALS patients and their family can shape one another's decisions pertaining to care.

\section{Methods}

Search strategy

We undertook a review of peer-reviewed empirical research published in full and in English between January 2007 and January 2017, relating to patient and family decision-making in ALS care. Databases searched included: Medline; CINAHL; AMED; PsycINFO; PsycARTICLES; and Social Sciences Full Text. The following search terms were used in multiple 'and' and 'and/or' combinations: amyotrophic lateral sclerosis; motor neurone disease; patient; family caregivers; caregivers; family carers; carers; family 
members; decision making; decision making process; preferences; perceptions; experiences; care; health care; services; and palliative care.

Inclusion/exclusion criteria

We systematically extracted studies which captured ALS patients' and/or family members' (of ALS patients) preferences for care or decision making in care, in which data was obtained from the patient and/or family member. However, as our aim was to examine the patient/family relationship in the decision-making process, we excluded studies that focused only on the patient or only on the family if there was no reference to the other. We excluded all non-empirical records, non-original research articles, feasibility studies and single-case studies. Finally, we excluded studies that pertained only to the neuroscience and/or neuropsychology of decision-making in ALS (i.e. without reference to how the cognitive function of ALS patients impacted on their decision-making in care or on decision-making processes pertaining to care). Given that studies on decision-making in healthcare fall into evidence levels of III and below, appraisal pertaining to rigour and validity standard in systematic reviews on interventions was not appropriate. We included all studies that fitted the inclusion criteria regardless of evidence level or study design. Figure 1 outlines how the results were systematically extracted.

\section{Analysis}

Given the diversity of study designs found, a narrative synthesis was conducted (10). First, all studies were critically appraised. Similarities and differences between studies were explored. We then synthesised and interpreted the evidence as it related to the aims of the review. We adopted a narrative approach in our synthesis of the evidence. 


\section{Findings}

We systematically extracted 47 studies (55 texts) from the empirical literature. Table 1 (supplementary material) details all of these studies. Our synthesis resulted in the categorisation of the findings as follows:

\section{Sourcing information about ALS}

Surveys have been undertaken at Italian and German specialised ALS clinics on patients' and family caregivers' preferences for seeking and receiving information $(11,12)$. Both patients and their family caregivers placed high priority on information pertaining to research, prognosis and disease-modifying treatments in ALS (11). The majority of patients and family caregivers decided to search for information outside of the clinical encounter $(11,12)$. However, in the Italian-based study (11), family caregivers reported higher use of external information sources when compared to patients.

\section{Life-prolonging and life-ending interventions}

A number of studies have focused on decision making in life-prolonging interventions (i.e. invasive and non-invasive ventilation, gastrostomy) and in life-ending interventions (i.e. physician-assisted suicide, withdrawal of invasive ventilation) (13-28). A German-based prospective study on patient medical decision-making in ALS (13) showed that neither moderate cognitive impairment nor behavioural change (behavioural change as rated by the caregiver) were associated with patients' use or decline of gastrostomy and ventilation or with their desire for hastened death. 
Large-scale quantitative (prospective, cross-sectional and retrospective) studies have captured the impact or potential impact that family caregivers can have on patients' decisions pertaining to the above interventions (14-17). A retrospective study undertaken in Japan (14) identified that the presence of a spouse was a significant factor in patients' choice to undergo invasive ventilation. In the United States and Japan, disparity between patients' and family carers' preferences for invasive ventilation has been identified with family caregivers favouring invasive ventilation more than patients (15). Japanese family caregivers were significantly more in favour of invasive ventilation than were Japanese patients. In a UK population-based study, family carers' good ratings on palliative care outcomes were associated with patients' refusal of gastrostomy and non-invasive ventilation (16). Caregivers with lower caregiver strain and higher levels of psychological wellbeing were likely to be caregivers of patients who refused interventions (16). A Dutch survey on end-of-life practices in ALS showed that patients who chose euthanasia or physician-assisted suicide were more likely to die at home with the support of family (17).

Qualitative studies have investigated ALS patients' and their family caregivers' perspectives on ventilation and/or gastrostomy (18-25). At a specialised clinic in the UK, patients and their family caregivers encountered psychological and physical challenges in using gastrostomy and non-invasive ventilation but engaged with these interventions because of the dual benefits it derived for both patients and family caregivers (18-21). Indeed, findings from a different UK-based ALS clinic (22) revealed that family enabled patients to share the burden of decision making in the above interventions. Other qualitative studies identified that family caregivers in ALS invariably chose to take on the burden of care associated with assisted ventilation because of the positive effects experienced by their loved one from the intervention $(24,25)$. Notwithstanding differences between patients' and family caregivers' 
wishes (e.g. family caregivers wanting more information about ventilation when compared to patients, family caregivers wanting patients to plan future care when patients did not feel ready to do so), patients were keen to minimise burden on their family caregiver and family caregivers felt the need to advocate on behalf of the patient (25).

The ALS patient and family caregiver commitment to one another has been reported in other studies on decision-making in ventilation (26-28). In a Danish study on withdrawal of invasive ventilation (26), the reason for request by patients for withdrawal was a general loss of meaning in their life. Interviews conducted with family caregivers after withdrawal identified that even though family caregivers were apprehensive about the death scenario, they supported procedures in accordance with patients' wishes. Retrospective and mixed-methods studies in Japan found that ALS patients' decisions about invasive ventilation were influenced by their own concerns for and obligation to family members. Although patients feared becoming a burden on their family (by choosing invasive ventilation), they also desired to live on with invasive ventilation in order to be available to their children and grandchildren $(27,28)$.

\section{Advance care planning}

Family caregivers of people with ALS have felt more anxious than their ALS partner about having to make decisions about future care (29). Nevertheless, a survey among bereaved family caregivers revealed that family caregivers of people with ALS had been more aware of their loved one's choices for future care when compared to family caregivers of people who had neurodegenerative conditions of longer disease trajectory (30). A prospective-cohort study in the United States found that ALS patients and their family members were more likely to have had advance care planning discussions with physicians when compared to advanced cancer patients and their family members (31). 
Studies have reported on ALS patients' and their family members' perspectives on advance planning for life-prolonging interventions (e.g. ventilation) and end-of-life care interventions (e.g. DNR, preferred place of death) (32-35). A retrospective study at a specialised ALS clinic found that the majority of patients had preferred to die at home with the support of family (32). Interviews with ALS patients and family caregivers in the same region about their experiences of palliative care revealed that patients and their family caregivers invariably sought discussions about advance care planning (33). Studies of bereaved ALS family caregivers' perspectives on the use of advance directives have been conducted in the UK and in Australia $(34,35)$. The benefits of having engaged with advance directives as perceived by family caregivers, included increased patient autonomy, greater clarity among the wider family about the patient's wishes, and the easing of difficult decisions at the end of life for both patient and family caregivers $(34,35)$. However, readiness to accept the approaching death can influence when patients and their family caregivers engage with advance directives (34).

Longitudinal and cross-sectional studies have investigated ALS patients' preferences for family member involvement in healthcare decision-making at the end of life $(36,37)$ and family members' understanding of patients' preferences for family involvement in healthcare decision-making at the end of life $(38,39)$. Findings revealed that patients valued either independent decision-making or shared decision-making more so than deferring decision making in full to family $(36,37)$. In the event of patient decisional incapacity, preferences for decision making among patients as described above remained stable overtime (37). However, in some cases, family members were not able to identify correctly patients' preferences for family involvement in decision making - where family members identified the patient's 
preference as independent decision-making, some patients had a preference for shared decision-making or for relying on family members to make decisions about care (38).

\section{Genetic testing and family reproduction}

Decision-making among ALS family members in relation to genetic testing and family reproduction has been reported $(40,41)$. Interviews with family members who were at $50 \%$ risk of developing familial ALS (40) illustrated that those who chose not to have children tended to have more direct exposure to ALS and more experience of caring for a family member with ALS than those who chose to have children. The potential loss of a parent for a child remained participants' primary concern. Parenthood as a contextual factor in the decision-making process has also been identified in a study on the impact of presymptomatic testing in familial ALS (41). Findings showed that participants' (who were at risk of developing familial ALS) concerns about the consequences of having children in families with familial ALS were found to be primary motivating factors to learn results of genetic testing. A survey of ALS patients' preferences for genetic testing found that the majority of participants would support their adult children to engage with genetic testing (42).

\section{Support seeking}

A qualitative study in Sweden (43) revealed that family caregivers' distress about the prognosis of the person with ALS made them reluctant to seek support from healthcare services. Qualitative and mixedmethods studies undertaken in the UK (44-47), Australia (48), Italy (49) and Germany (50), identified that family caregivers and patients would have preferred more support (including diagnostic care, home care, counselling, assistive and adapted equipment, respite care and bereavement care) than that which 
had been offered to them (44-50). Family caregivers engaged openly with palliative care services and prioritised their caring role amidst their own feelings of loss (48). However, despite patients' and family caregivers' preference for additional support, some patients' and family caregivers' desire to maintain control and normality in their lives meant that they did not immediately engage with support services when support was offered to them (46). Moreover, family caregivers' obligation to care for the patient meant that family caregivers on occasions, deferred support services $(45,46)$.

Family reliance and responsibility

US-based surveys of ALS patients' communication needs in the final months of life found that communication about family and caregiving was important to patients (51). Family caregivers assisted patients to communicate with service providers. Reliance on family members to participate in the decision-making process has been reported by ALS patients (52).

Qualitative studies have captured how patient reliance on family caregivers shapes how family caregivers engage with services (53-59). A study in South Korea revealed that family caregivers felt burdened in their new role as decision maker for the family and were reluctant gatekeepers for services (53). Other studies also found that family caregivers faced significant challenges negotiating between patients' needs and other competing needs (54-59), including other family responsibilities (55). However, despite these challenges, family caregivers continued to prioritise their caring role and sought to manage available support and services out of commitment to their loved one (54-59). In some cases, family disruption associated with caring for a person with ALS strengthened relationships among family members (56). 
Biographical accounts of living with ALS have revealed that although ALS patients considered ending their lives, they chose to live on with ALS, in part because of the emotional support they received from family (60). An Irish-based qualitative study showed that patients were grateful to family for their support (8). However, in this study, patients' decisions about care were shaped by their own feelings of obligation toward their family. Perceived responsibilities as parents or indeed freedom from such responsibilities, was a key factor in shaping participants' decisions about care (61). A study of decision making in multidisciplinary care showed that both patients and their family caregivers felt a responsibility to one another in the decision-making process (62-64). In most cases, patients framed their care goals in the context of family members' needs (62) and despite the challenges encountered by both groups in negotiating care (e.g. change to patient communication and cognition, burden of care), family caregivers were keen to promote the patient viewpoint when engaging with services (63).

\section{Summary analysis}

Not all studies have been conducted where the primary focus was on decision making in care.

Qualitative investigations have centred on the overall experience of living with ALS and/or experience of care $(8,33,43,45,47,48,52-61)$ in addition to decision making in different domains of care (18-

$25,34,35,40,41,44,50,62-64)$. Of the quantitative and mixed-methods studies extracted $(11-17,26-32,36-$ $39,42,46,49,51)$, approximately half of them focused primarily on decision making in care $(13,14,16,27$ 29,31,36-39). 
A small number of studies sampled from population-based registers $(8,16,22,23,61)$. The majority of studies have sampled patients and their family members via specialised ALS clinics or neurology clinics. The sample size is small in the majority of studies. A small number of studies include other diagnostic groups and their family members $(30,31,37-39,50,52)$. In most cases, family members sampled were family caregivers rather than family members without caregiver duties. Only one study stated specifically that it was focused on the experiences of family members who did not have caregiving duties (56).

Of the studies which involved patient participation, only half of these studies reported that they screened patients for cognitive impairment prior to the study $(12-14,16,18-20,27-29,31,36-38,49)$ and only a small number of studies reported what assessments they used in order to screen patients for cognitive impairment $(13,16,31,36-38)$. Only two studies reported that they used neuropsychological measurements that are sensitive to the cognitive and/or behavioural profile of ALS $(13,16)$. Of note, the majority of studies that screened patients for cognitive impairment excluded patients who had clinically overt dementia $(12-14,18-20,27-29,49)$ or cognitive impairment based on the tests used to screen participants (31,36-38). Two studies indicated explicitly that they did not exclude patients on the basis of cognitive impairment $(22,61)$.

Only one prospective population-based study was identified (16) and few studies are prospective in design $(13,16,29,31,37)$. Many studies are surveys $(11,12,15,17,30,38,42,51)$ and over half of the studies extracted are qualitative. Qualitative design has been employed to explore participants' perspectives on interventions (22) not possible to capture in a quantitative study from the same population (16). A small number of studies reported using patient/family member decision-making scales (36-38). In some cases, 
findings pertaining to the patient are based on proxy reports obtained from family $(17,21,23,30,31,34,51)$.

Overall, the studies extracted vary substantially in scope and design. In some cases, findings differ between studies that investigated similar domains of care. The differences between findings could be attributed to purposeful sampling procedures, small sample sizes and variation between contexts. Indeed, a large number of studies are qualitative and in these cases, findings cannot be generalised to the wider population of ALS patients and their family members.

\section{Discussion}

The findings of this review highlight the complexity of decision making among ALS patients and their family. Both ALS patients and their family caregivers can value information about ALS $(11,12)$ but family caregivers may seek more information about ALS than patients seek for themselves $(11,25)$. Patients' and their family caregivers' need to feel in control can influence when they engage with services $(34,46)$. Family can directly or indirectly impact on whether patients request, accept or decline interventions $(14,16,17,22,27,28,61,62)$. Family caregivers engage with patients in advance care planning $(30,33-35)$ and can support patients' expressed wishes for care $(26,63)$. Although patients resist becoming a burden on family $(8,25,28,33,62)$, some may also prefer to die at home with the support of family $(17,32,33)$. Importantly, patients can be dependent on family in order to participate in the clinical encounter $(51,52,62-64)$.

Notwithstanding the differences between ALS patients and family caregivers in their preferences for care $(11,15,25)$ or indeed the misunderstandings that family members might have about patients' 
preferences for care $(36,38)$, ALS patients can value support rendered to them by their family $(8,60,61)$ and in some cases, prefer to share decision making with family members $(22,36,37,62)$. In many cases, ALS patients' and their family caregivers' decisions about care can be swayed by their desire to minimise distress for the other (18-21,24-28,34,35,48,54-64). The concerns that ALS patients, their family caregivers, and family members at known risk of ALS have for the wider family, is a key factor that shapes decision-making processes within the ALS family unit $(8,24,27,28,34,40-42,52,53,55,61,62)$.

The findings of this review have a number of implications for ALS research and practice. Not only are patients and family caregivers co-dependent in the decision making process, both patients' and family caregivers' decisions about care are shaped by their obligation to the wider family. However, as reported, the family member perspective in ALS has been captured primarily from family caregivers as opposed to family members without caregiver duties. The philosophy of the palliative care approach underpins the patient and family as the unit of care (65). The challenge for healthcare professionals in ALS care is to engage family caregivers and the wider family in the decision-making process whilst enabling patients to make decisions about their care. Attention to how family members who do not have direct caregiving responsibilities impact on the decision-making process would broaden our understanding of familial processes that underpin decision-making in ALS care and help guide healthcare professionals on how to accommodate the wider family in ALS care.

As identified, the majority of studies which captured the patient perspective did not screen participants for cognitive impairment. Severe fronto-temporal impairment in ALS can impact on patient decisionmaking in care and on the relationship between patients and their family members. This is not to suggest that ALS patients with overt cognitive impairment be excluded from the decision-making 
process (66) or from research focused on decision-making in care (22). However, few guidelines exist on how to include ALS patients who have cognitive impairment in the decision-making process. Indeed, questions prevail as to what extent healthcare decision-making among ALS patients who have mild to moderate cognitive and behavioural impairment is reflective of healthcare decision-making among ALS patients who do not have cognitive and behavioural impairment (13).

\section{Limitations of review}

This review has focused only on the ALS patient and the family member. The review has not reported on the experiences of healthcare providers or healthcare professionals who interface with ALS patients and their family members in the decision-making process. We only included empirical studies published in full and in English. We also limited our review to a 10-year period. Studies were not excluded based on the evidence level of the study.

\section{Conclusions}

Attention to ALS family member roles in the decision-making process beyond that of the primary caregiver role is needed. More focus on strategies that integrate cognitively-impaired ALS patients into the decision-making process and that facilitate their participation with family in research related to their care, is required. Identification of the substantive domains in which ALS patients and their family members support one another in the decision-making process is a precursor to developing patient/family decision-making tools in ALS care.

\section{Declaration of interest}


The authors report no conflict of interest.

ORCID

Geraldine Foley ID http://orcid.org/0000-0001-7952-9246

\section{References}

1. Andersen PM, Abrahams S, Borasio GD, de Carvahlo M, Chio A, Van Damme $P$, et al. EFNS guidelines on the clinical management of amyotrophic lateral sclerosis (MALS) - revised report of an EFNS task force. Eur J Neurol 2012;19: 360-375.

2. Stephens HE, Felgoise S, Young J, Simmons Z. Multidisciplinary ALS clinics in the USA: A comparison of those who attend and those who do not. Amytroph Lateral Scler Frontotemporal Degener 2015;16: 196-201.

3. Oliver D, Borasio GD, Johnston W (eds). Palliative care in amyotrophic lateral sclerosis. From diagnosis to bereavement. $3^{\text {rd }}$ ed. Oxford: Oxford University Press, 2014.

4. Oliver DJ, Turner MR. Some difficult decisions in ALS/MND. Amytroph Lateral Scler 2010;11: 339343.

5. Siminoff LA. Incorporating patient and family preferences into evidence-based medicine. BMC Med Inform Decis Mak 2013;13 Suppl 3:S6

6. Aoun S, Bentley B, Funk L, Toye C, Grande G, Stajduhar KJ. A 10-year literature review of family caregiving for motor neurone disease: moving from caregiver burden studies to palliative care interventions. Palliat Med 2013;27: 437-446 
7. Hughes RA, Sinha A, Higginson I, Down K, Leigh PN. Living with motor neurone disease: lives, experiences of services and suggestions for change. Health Soc Care Community 2005;13: 64-74.

8. Foley G, Timonen V, Hardiman O. "I hate being a burden": the patient perspective on carer burden in amyotrophic lateral sclerosis. Amyotroph Lateral Scler Frontotemporal Degener 2016;17: 351-357.

9. Wallace CL. Family communication and decision making at the end of life: a literature review. Palliat Support Care 2015;13:815-825

10. Pope C, Mays N, Popay J. Synthesising qualitative and quantitative health evidence. A guide to methods. Maidenhead: Open University press, 2007, p.102

11. Chio A, Montuschi S, Cammarosano S, De Mercanti S, Cavallo E. ALS patients and caregivers communication preferences and information seeking behaviour. Eur J Neurol 2008;15: 51-56.

12. Abdulla S, Vielhaber S, Machts J, Heinze HJ, Dengler R. Information needs and informationseeking preferences of ALS patients and their carers. Amyotroph Lateral Scler Frontotemporal Degener 2014;15: 505-512.

13. Böhm S, Aho-Özhan HE, Keller J, Dorst J, Uttner I, Ludolph AC, et al. Medical decisions are independent of cognitive impairment in amyotrophic lateral sclerosis. Neurology 2016;87: 17371738.

14. Tagami M, Kimura F, Nakajima H, Ishida S, Fujiwara S, Doi Y, et al. Tracheostomy and invasive ventilation in Japanese ALS patients: decision-making and survival analysis: 1990-2010. J Neurol Sci 2014;344: 158-164.

15. Rabkin J, Ogino M, Goetz R, McElhiney M, Hupf J, Heitzman D, et al. Japanese and American ALS patient preferences regarding TIV (tracheostomy with invasive ventilation): A cross-national survey. Amyotroph Lateral Scler Frontotemporal Degener 2014:15: 185-191. 
16. Martin NH, Landau S, Janssen A, Lyall R, Higginson I, Burman R, et al. Psychological as well as illness factors influence acceptance of non-invasive ventilation (NIV) and gastrostomy in amyotrophic lateral sclerosis (ALS): A prospective population study. Amyotroph Lateral Scler Frontotemporal Degener 2014;15: 376-387

17. Maessen M, Veldink JH, Onwuteaka-Philipsen BD, de Vries JM, Wokke JH, van der Wal G, et al. Trends and determinants of end-of-life practices in ALS in the Netherlands. Neurology 2009;73: 954-961.

18. Stavroulakis T, Baird WO, Baxter SK, Walsh T, Shaw PJ, McDermott CJ. The impact of gastrostomy in motor neurone disease: challenges and benefits from a patient and carer perspective. BMJ Support Palliat Care 2016;6: 52-59.

19. Stavroulakis T, Baird WO, Baxter SK, Walsh T, Shaw PJ, McDermott CJ. Factors influencing decision-making in relation to timing of gastrostomy insertion in patients with motor neurone disease. BMJ Support Palliat Care 2014;4: 57-63.

20. Baxter SK, Baird WO, Thompson S, Bianchi SM, Walter SJ, Lee E, et al. The initiation of noninvasive ventilation for patients with motor neuron disease: Patient and carer perceptions of obstacles and outcomes. Amyotroph Lateral Scler Frontotemporal Degener 2013;14: 105-110.

21. Baxter SK, Baird WO, Thompson S, Bianchi SM, Walter SJ, Lee E, et al. The use of non-invasive ventilation at end of life in patients with motor neurone disease: A qualitative exploration of family carer and health professional experiences. Palliat Med 2013;27: 516-523.

22. Greenaway LP, Martin NH, Lawrence V, Janssen A, Al-Chalabi A, Leigh PN, et al. Accepting or declining non-invasive ventilation or gastrostomy in amyotrophic lateral sclerosis: patients' perspectives. J Neurol 2015;262; 1002-1013. 
23. Veronese S, Valle A, Chio A, Calvo A, Oliver D. The last months of life of people with amyotrophic lateral sclerosis in mechanical invasive ventilation: A qualitative study. Amyotroph Lateral Scler Frontotemporal Degener 2014;15: 499-504.

24. Sundling IM, Ekman SL, Weinberg J, Klefbeck B. Patients' with ALS and caregivers' experiences of non-invasive home ventilation. Adv Physiother 2009;11: 114-120.

25. Lemoignan J, Ells C. Amyotrophic lateral sclerosis and assisted ventilation: How patients decide. Palliat Support Care 2010;8: 207-213.

26. Dreyer PS, Felding M, Klitnaes CS, Lorenzen CK. Withdrawal of invasive home mechanical ventilation in patients with advanced amyotrophic lateral sclerosis: Ten years of Danish experience. J Palliat Med 2012;15: 205-209.

27. Kurisaki R, Yamashita S, Sakamoto T, Maruyoshi N, Uekawa K, Uchino M, et al. Decision making of amyotrophic lateral sclerosis patients on noninvasive ventilation to receive tracheostomy positive pressure ventilaton. Clin Neurol Neurosurg 2014;125: 28-31.

28. Hirano Y, Yamazaki Y. Ethical issues in invasive mechanical ventilation for amyotrophic lateral sclerosis. Nurs Ethics 2010;17: 51-63.

29. McKim DA, King J, Walker K, Le Blanc C, Timpson D, Wilson KG, et al. Formal ventilation patient education for ALS predicts real-life choices. Amyotroph Lateral Scler 2012;13: 59-65.

30. Goy ER, Carter J, Ganzini L. Neurologic disease at the end of life: Caregiver descriptions of Parkinson disease and amyotrophic lateral sclerosis. J Palliat Med 2008;11: 548-554.

31. Astrow AB, Sood JR, Nolan MT, Terry PB, Clawson L, Kub J, et al. Decision-making in patients with advanced cancer compared with amyotrophic lateral sclerosis. J Med Ethics 2008;34: 664668. 
32. Chhetri SK, Bradley BF, Callagher P, Addison-Jones R, Bennett W, Gardham J, et al. Choosing the place of death: Empowering motor neurone disease/amyotrophic lateral sclerosis patients in end-of-life decision making. Palliat Med 2015;29: 667-668.

33. Whitehead B, O'Brien MR, Jack BA, Mitchell D. Experiences of dying, death and bereavement in motor neurone disease: A qualitative study. Palliat Med 2012;26: 368-378.

34. Murray L, Butow PN, White K, Kiernan MC, D'Abrew N, Herz H. Advance care planning in motor neuron disease: A qualitative study of caregiver perspectives. Palliat Med 2016;30: 471-478.

35. Preston H, Fineberg IC, Callagher P, Mitchell DJ. The Preferred Priorities for Care document in motor neurone disease: Views of bereaved relatives and carers. Palliat Med 2012;26: 132-138.

36. Nolan MT, Kub J, Hughes MT, Terry PB, Astrow AB, Carbo CA, et al. Family health care decision making and self-efficacy with patients with ALS at the end of life. Palliat Support Care 2008;6: 273-280.

37. Sulmasy DP, Hughes MT, Thompson RE, Astrow AB, Terry PB, Kub J, et al. How would terminally ill patients have others make decisions for them in the event of decisional incapacity? A longitudinal study. J Am Geriatr Soc 2007;55: 1981-1988.

38. Sharma RK, Hughes MT, Nolan MT, Tudor C, Kub J, Terry PB, et al. Family understanding of seriously-ill patient preferences for family involvement in healthcare decision making. J Gen Intern Med 2011;(8): 881-886.

39. Nolan MT, Hughes MT, Kub J, Terry PB, Astrow A, Thompson RE, et al. Development and validation of the Family Decision-Making Self-Efficacy Scale. Palliat Support Care 2009;7: 315321.

40. Hartzfeld DE, Siddique N, Victorson D, O’Neill S, Kinsley L, Siddique T. Reproductive decisionmaking among individuals at risk for familial amyotrophic lateral sclerosis. Amyotroph Lateral Scler Frontotemporal Degener 2015;16: 114-119. 
41. Fanos JH, Gronka S, Wuu J, Stanislaw C, Anderson PM, Benatar M. Impact of pre-symptomatic testing for familial amyotrophic lateral sclerosis. Genet Med 2011;13: 432-348.

42. Wagner KN, Nagaraja H, Allain DC, Quick A, Kolb B, Roggenbuck J. Patients with amyotrophic lateral sclerosis have a high interest in and limited access to genetic testing. J Genet Counsel 2016 Oct 20 [Epub ahead of print]

43. Ozanne AO, Graneheim UH, Strang S. Struggling to find meaning in life among spouses of people with ALS. Palliat Support Care 2015;13: 909-916.

44. O'Brien MR, Whitehead B, Jack BA, Mitchell JD. From symptom onset to a diagnosis of amyotrophic lateral sclerosis/motor neuron disease (ALS/MND): Experiences of people with ALS/MND and family carers - a qualitative study. Amyotroph Lateral Scler 2011;12: 97-104.

45. O’Brien MR, Whitehead B, Jack BA, Mitchell JD. The need for support services for family carers of people with motor neurone disease (MND): views of current and former caregivers a qualitative study. Disabil Rehabil 2012;34: 247-256.

46. O’Brien MR, Whitehead B, Murphy PN, Mitchell JD, Jack BA. Social services homecare for people with motor neurone disease/amyotrophic lateral sclerosis: Why are such services used or refused? Palliat Med 2012;26: 123-131.

47. O’Brien M, Whitehead B, Jack B, Mitchell JD. Multidisciplinary team working in motor neurone disease: patient and family carer views. Br J Neur Sci Nurs 2011;7: 580-585.

48. Aoun SM, Connor SE, Priddis L, Breen LJ, Colyer S. Motor Neurone Disease family carers' experiences of caring, palliative care and bereavement: An exploratory study. Palliat Med 2012;26: 842-850.

49. Mannino M, Cellura E, Grimaldi G, Volanti P, Piccoli F, La Bella V. Telephone follow-up for patients with amyotrophic lateral sclerosis. Eur J Neurol 2007;14: 79-84. 
50. Henschke C. Provision and financing of assistive technology devices in Germany: a bureaucratic odyssey? The case of amyotrophic lateral sclerosis and Duchenne muscular dystrophy. Health Policy 2012; 105: 176-184.

51. Brownlee A, Bruening LM. Methods of communication at end of life for the person with amyotrophic lateral sclerosis. Top Lang Disorders 2012;32: 168-185.

52. Morris MA, Dudgeon BJ, Yorkston K. A qualitative study of adult AAC users' experiences communicating with medical providers. Disabil Rehabil Assist Technol 2013;8: 472-481.

53. Hyunjin O, Schepp KG. Wives becoming caregivers: the lived experiences of wives caring for amyotrophic lateral sclerosis patients. J Hosp Palliat Nurs 2013;15: 244-250.

54. Anderson NH, Gluyas C, Mathers S, Hudson P, Ugalde A. "A monster that lives in our lives": experiences of caregivers of people with motor neuron disease and identifying avenues for support. BMJ Support Palliat Care 2016 April 28 [Epub ahead of print]

55. Lerum SV, Solbraekke KN, Frich JC. Family caregivers' accounts of caring for a family member with motor neurone disease in Norway: a qualitative study. BMC Palliat Care 2016;15: 22.

56. Cipolletta S, Amicucci L. The family experience of living with a person with amyotrophic lateral sclerosis: A qualitative study. Int J Psychol 2015;50: 288-294.

57. Larsson BJ, Frojd C, Nordin K, Nygren I. Relatives of patients with amyotrophic lateral sclerosis: Their experience of care and support. Palliat Support Care 2015;13: 1569-1577.

58. Ray RA, Street AF. Non-finite loss and emotional labour: family caregivers' experiences of living with motor neurone disease. J Clin Nurs 2007;16: 35-43.

59. Ray RA, Street AF. The dynamics of socio-connective trust within support networks accessed by informal caregivers. Health 2011;15: 137-152.

60. Rosengren K, Gustafsson I, Jarnevi E. Every second counts: Women's experiences of living with ALS in the end-of-life situations. Home Health Care Manag Pract 2015;27: 76-82. 
61. Foley G, Timonen V, Hardiman O. Acceptance and decision making in amyotrophic lateral sclerosis from a life-course perspective. Qual Health Res 2014;24: 67-77.

62. Hogden A, Greenfield D, Nugus P, Kiernan MC. What influences patient decision-making in amyotrophic lateral sclerosis multidisciplinary care? A study of patient perspectives. Patient Prefer Adherence 2012;6: 829-838.

63. Hogden A, Greenfield D, Nugus P, Kiernan MC. What are the roles of carers in decision-making for amyotrophic lateral sclerosis multidisciplinary care? Patient Prefer Adherence 2013;7: 171181.

64. Hogden A, Greenfield D, Nugus P, Kiernan MC. Development of a model to guide decision making in amyotrophic lateral sclerosis multidisciplinary care. Health Expect 2015;18: 17691782.

65. Connor SR. Hospice and palliative care: The essential guide. $2^{\text {nd }}$ ed. New York: Taylor \& Francis, 2009.

66. Foley G. Cognitive and behavioural impairment in ALS: what now for the ALS patient perspective? Amytroph Lateral Scler Frontotemporal Degener 2015;16: 423-424.

\section{Biographical note}

Geraldine Foley PhD is an Assistant Professor (Occupational Therapy) in the School of Medicine, Trinity College Dublin, Ireland. She is a previous Health Research Board (Ireland) Research Fellow at Trinity College Dublin.

Geralyn Hynes PhD is an Associate Professor and Director of Research in the School of Nursing and Midwifery, Trinity College Dublin, Ireland. She is a former lecturer of Nursing at the Royal College of Surgeons, Ireland. 
Figure 1. PRISMA flow diagram summarising search

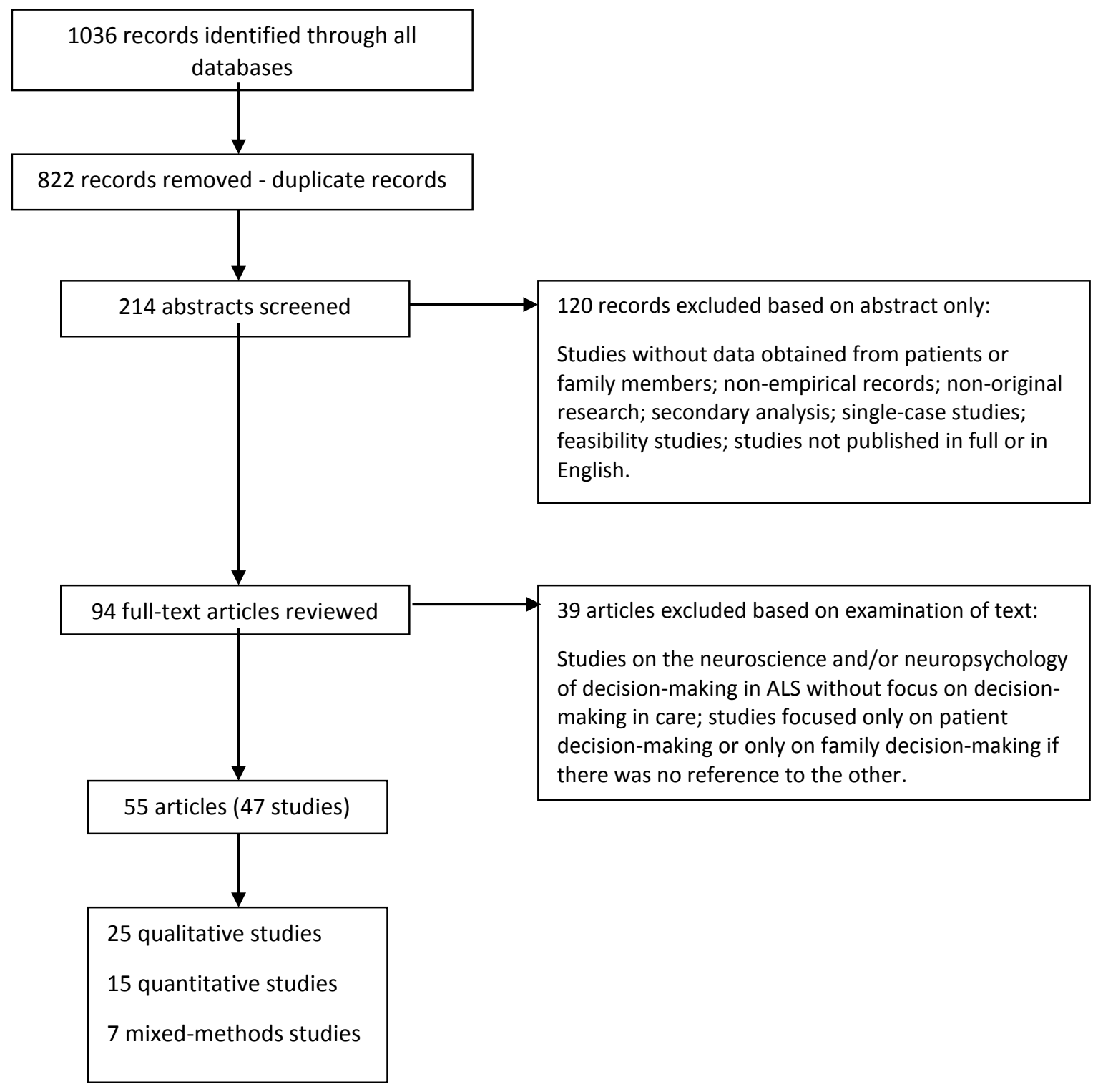


Table 1. Summary of studies included in review

\begin{tabular}{|c|c|c|c|c|c|}
\hline Study & $n=$ & Location & Methods & Primary focus of study & Findings \\
\hline Abdulla et al. 2014 (12) & $\begin{array}{l}n=106 \text { ALS patients } \\
n=100 \text { caregivers [diad] } \\
\text { (including } n=96 \text { family } \\
\text { caregivers) }\end{array}$ & $\begin{array}{l}\text { Two ALS clinics: } \\
\text { Magdeburg and } \\
\text { Hannover, Germany }\end{array}$ & $\begin{array}{l}\text { Quantitative; survey } \\
\text { questionnaires, patient self- } \\
\text { rating functional scale }\end{array}$ & $\begin{array}{l}\text { To investigate information-seeking } \\
\text { behaviour in ALS patients and their } \\
\text { caregivers }\end{array}$ & $\begin{array}{l}\text { Before a physician appointment - } 28 \% \text { of patients and } \\
23 \% \text { of family caregivers had used other sources to } \\
\text { find symptom related information. Although two- } \\
\text { thirds of patients and family caregivers were satisfied } \\
\text { with disclosure, } 88 \% \text { of patients and } 85 \% \text { of caregivers } \\
\text { searched for additional information from multiple } \\
\text { sources including the internet, patient brochures and } \\
\text { support organisations. }\end{array}$ \\
\hline Anderson et al. 2016 (54) & $n=15$ family caregivers & $\begin{array}{l}\text { Progressive } \\
\text { neurological disease } \\
\text { clinic, Melbourne, } \\
\text { Australia }\end{array}$ & $\begin{array}{l}\text { Qualitative; semi-structured } \\
\text { interviews }\end{array}$ & $\begin{array}{l}\text { To investigate the ALS caregiver } \\
\text { experience in order to inform supportive } \\
\text { interventions for ALS caregivers }\end{array}$ & $\begin{array}{l}\text { Family caregivers felt a responsibility to provide care } \\
\text { to (and manage available support for) the person with } \\
\text { ALS. Family caregivers decided to actively engage with } \\
\text { service providers to help provide care. Family } \\
\text { caregivers strove to remain hopeful and resilient } \\
\text { despite their loss. }\end{array}$ \\
\hline Aoun et al. 2012 (48) & $\begin{array}{l}n=16 \text { bereaved family } \\
\text { caregivers }\end{array}$ & $\begin{array}{l}\text { MND Association of } \\
\text { Western Australia }\end{array}$ & $\begin{array}{l}\text { Qualitative; semi-structured } \\
\text { interviews, self-rated grief } \\
\text { measurement }\end{array}$ & $\begin{array}{l}\text { To explore ALS family caregivers' } \\
\text { experiences of care pre- and post- } \\
\text { bereavement }\end{array}$ & $\begin{array}{l}\text { Family caregivers actively engaged supportive and } \\
\text { palliative care services for the patient. Family } \\
\text { caregivers tended to prioritise their caring role over } \\
\text { their own needs amidst their own feelings of loss. Six } \\
\text { of } 10 \text { participants accepted bereavement support } \\
\text { when offered. }\end{array}$ \\
\hline Astrow et al. 2008 (31) & $\begin{array}{l}n=32 \text { ALS patients } \\
n=60 \text { patients (other } \\
\text { diagnosis) } \\
n=9 \text { family members (ALS) } \\
\text { [diad] } \\
n=27 \text { family members (other } \\
\text { diagnosis) [diad] }\end{array}$ & $\begin{array}{l}\text { Two specialised } \\
\text { teaching hospitals: } \\
\text { Baltimore and New } \\
\text { York, USA }\end{array}$ & $\begin{array}{l}\text { Mixed methods; baseline } \\
\text { patient Qol and health status } \\
\text { measures for patients, } \\
\text { prospective longitudinal } \\
\text { review of medical records for } \\
\text { patients' documented } \\
\text { preferences, and structured } \\
\text { interviews with family } \\
\text { members after patient death } \\
\\
\text { Patient cognitive status screened: } \\
\text { - Mental status questionnaire } \\
\text { - Confusion assessment method }\end{array}$ & $\begin{array}{l}\text { To compare decision making in advance } \\
\text { care planning between ALS patients and } \\
\text { advanced cancer patients }\end{array}$ & $\begin{array}{l}\text { ALS patients and their families were more likely than } \\
\text { cancer patients and their families to have had } \\
\text { advance care planning discussions surrounding their } \\
\text { wishes for ventilator support, artificial nutrition and } \\
\text { hydration (ANH), do not resuscitate (DNR) status and } \\
\text { hospice care. } \\
\text { Of the ALS patients who were known to have opted } \\
\text { for DNR, none of them received cardiopulmonary } \\
\text { resuscitation. } \\
\text { Patient age, race, gender, religion, health status and } \\
\text { quality of life were not associated with patients' } \\
\text { decisions to discuss ventilator support, ANH, DNR and } \\
\text { or hospice care with physicians. }\end{array}$ \\
\hline Baxter et al. $2013(20)$ & $\begin{array}{l}n=20 \text { ALS patients } \\
n=17 \text { family caregivers [diad] }\end{array}$ & $\begin{array}{l}\text { ALS clinic, Sheffield, } \\
\text { UK }\end{array}$ & $\begin{array}{l}\text { Qualitative; semi-structured } \\
\text { interviews }\end{array}$ & $\begin{array}{l}\text { To investigate ALS patients' and their } \\
\text { caregivers' perceptions of the obstacles } \\
\text { and outcomes of using non-invasive } \\
\text { ventilation }\end{array}$ & $\begin{array}{l}\text { Despite physical and psychological challenges in using } \\
\text { non-invasive ventilation, couples persevered with } \\
\text { non-invasive ventilation because of the benefits it } \\
\text { derived for both patients and family caregivers - } \\
\text { symptom management for patients and enhanced } \\
\text { caregiver wellbeing. Family caregivers felt a positive } \\
\text { impact from patients' gains. }\end{array}$ \\
\hline
\end{tabular}




\begin{tabular}{|c|c|c|c|c|c|}
\hline Baxter et al. 2013 (21) & $\begin{array}{l}n=9 \text { bereaved family } \\
\text { caregivers } \\
n=15 \text { healthcare } \\
\text { professionals }\end{array}$ & $\begin{array}{l}\text { ALS clinic, Sheffield, } \\
\text { UK }\end{array}$ & $\begin{array}{l}\text { Qualitative; semi-structured } \\
\text { interviews }\end{array}$ & $\begin{array}{l}\text { To describe ALS caregiver and healthcare } \\
\text { professional experiences of end-of-life } \\
\text { care using non-invasive ventilation with } \\
\text { ALS patients }\end{array}$ & $\begin{array}{l}\text { Family caregivers engaged with non-invasive } \\
\text { ventilation so that it could help aide patient comfort } \\
\text { and anxiety at the end of life. }\end{array}$ \\
\hline Böhm et al. 2016 (13) & $\begin{array}{l}n=169 \text { ALS patients } \\
n=140 \text { caregivers [diad] } \\
(n ?=\text { family caregivers })^{1}\end{array}$ & $\begin{array}{l}\text { ALS clinic, Ulm, } \\
\text { Germany }\end{array}$ & $\begin{array}{l}\text { Quantitative; prospective } \\
\text { cohort study: standardised } \\
\text { questionnaires (for patient } \\
\text { care decisions), Cognitive and } \\
\text { Behavioural ALS measure } \\
\text { [ECAS] (for patients) and } \\
\text { caregiver rating of patient } \\
\text { behavior [ECAS] }\end{array}$ & $\begin{array}{l}\text { To investigate if ALS patients' medical } \\
\text { decisions are independent of cognitive } \\
\text { impairment in ALS }\end{array}$ & $\begin{array}{l}\text { Moderate cognitive impairment or behavioural } \\
\text { change (as reported by caregivers) were not } \\
\text { associated with patients' decisions regarding } \\
\text { gastrostomy and ventilation or with their attitudes } \\
\text { towards hastening death. }\end{array}$ \\
\hline $\begin{array}{l}\text { Brownlee \& Bruening } \\
2012(51)\end{array}$ & $\begin{array}{l}n=625 \text { bereaved family } \\
\text { members or caregivers } \\
\text { ( } n=602 \text { bereaved family } \\
\text { members/family caregivers; } \\
\text { remainder of sample non- } \\
\text { family) }\end{array}$ & $\begin{array}{l}\text { ALS Association } \\
\text { Chapters, USA (across } \\
8 \text { states) }\end{array}$ & $\begin{array}{l}\text { Quantitative; survey } \\
\text { questionnaires }\end{array}$ & $\begin{array}{l}\text { To identify the communication needs of } \\
\text { ALS patients and the range of } \\
\text { communication strategies used by them } \\
\text { in the final months of life }\end{array}$ & $\begin{array}{l}\text { Physical needs, caregiving issues and family issues } \\
\text { were important topics for patients to communicate } \\
\text { about at the end of life. Family caregivers assisted } \\
\text { patients to communicate with service providers. }\end{array}$ \\
\hline Chhetri et al. 2015 (32) & $n=99 \mathrm{ALS}$ patients & ALS clinic, Preston, UK & $\begin{array}{l}\text { Quantitative; retrospective } \\
\text { review of case notes and } \\
\text { patients' stated preferences } \\
\text { in the patient Preferred } \\
\text { Priorities for Care (PCC) } \\
\text { Document }\end{array}$ & $\begin{array}{l}\text { To investigate whether ALS patients' } \\
\text { completion of PPC document affected } \\
\text { actual place of death or hospital use } \\
\text { towards end-of-life }\end{array}$ & $\begin{array}{l}\text { The majority of patients who had documented } \\
\text { preferred place of death indicated that home with } \\
\text { family was their preferred place of death. } \\
\text { Patients who did not complete the PCC were more } \\
\text { likely to die in hospital. } \\
\text { The main reason for non-completion of the PCC was } \\
\text { patient reluctance to discuss end-of-life care issues. }\end{array}$ \\
\hline Chio et al. 2008 (11) & $\begin{array}{l}n=60 \text { ALS patients } \\
n=60 \text { caregivers [diad] } \\
\text { (including } n=56 \text { family } \\
\text { caregivers) }\end{array}$ & ALS clinic, Turin, Italy & $\begin{array}{l}\text { Quantitative; survey } \\
\text { questionnaire }\end{array}$ & $\begin{array}{l}\text { To evaluate information preferences and } \\
\text { information seeking behaviour among ALS } \\
\text { patients and their caregivers }\end{array}$ & $\begin{array}{l}\text { Both patients and family caregivers indicated that } \\
\text { research, disease-modifying treatments and } \\
\text { outcomes in ALS were the most important domains to } \\
\text { be informed about during disclosure. } \\
\text { Approximately } 55 \% \text { of patients and } 83 \% \text { of caregivers } \\
\text { searched for information from resources outside of } \\
\text { healthcare system (e.g. internet). }\end{array}$ \\
\hline $\begin{array}{l}\text { Cipolletta \& Amicucci } \\
2015 \text { (56) }\end{array}$ & $\begin{array}{l}n=13 \text { bereaved family } \\
\text { members (including } n=4 \\
\text { bereaved primary family } \\
\text { caregivers) }\end{array}$ & $\begin{array}{l}\text { ALS website } \\
\text { (ww.slaitalia.it), Italy }\end{array}$ & $\begin{array}{l}\text { Qualitative; semi-structured } \\
\text { interviews }\end{array}$ & $\begin{array}{l}\text { To explore the experience of family } \\
\text { members who lived with ALS patients } \\
\text { until their death }\end{array}$ & $\begin{array}{l}\text { Family caregivers engaged with services despite } \\
\text { perceiving limitations in services. Family caring for a } \\
\text { person with ALS strengthened relationships between } \\
\text { family members (in the case of } 10 \text { families). The } \\
\text { challenges encountered living with ALS weakened } \\
\text { family relationships in the case of three families. }\end{array}$ \\
\hline
\end{tabular}




\begin{tabular}{|c|c|c|c|c|c|}
\hline Dreyer et al. 2012 (26) & $\begin{array}{l}n=12 \text { ALS patients } \\
n=10 \text { bereaved family } \\
\text { caregivers [diad] }\end{array}$ & $\begin{array}{l}\text { Respiratory centre, } \\
\text { Aarhus, Denmark }\end{array}$ & $\begin{array}{l}\text { Mixed methods; quantitative } \\
\text { descriptive (retrospective), } \\
\text { structured interviews (with } \\
\text { family caregivers) }\end{array}$ & $\begin{array}{l}\text { To describe the medical and ALS patient- } \\
\text { related aspects of terminating invasive } \\
\text { home ventilation }\end{array}$ & $\begin{array}{l}\text { The reason for requesting termination of ventilation } \\
\text { (for all patients) was loss of meaning in life. Family } \\
\text { caregivers supported procedures in accordance with } \\
\text { patients' best wishes. }\end{array}$ \\
\hline Fanos et al. $2011(41)$ & $\begin{array}{l}n=20 \text { family members at risk } \\
\text { for developing familial ALS }\end{array}$ & Pre-fALS study, USA & $\begin{array}{l}\text { Qualitative; semi-structured } \\
\text { interviews }\end{array}$ & $\begin{array}{l}\text { To explore participants' (who were at risk } \\
\text { of developing familial ALS) decisions } \\
\text { whether or not to learn results of pre- } \\
\text { symptomatic testing in ALS and to } \\
\text { understand the psychosocial impact of } \\
\text { these decisions }\end{array}$ & $\begin{array}{l}\text { Participants concerns' about the consequences of } \\
\text { having children in families with familial ALS were } \\
\text { found to be primary motivating factors to obtain } \\
\text { results of genetic testing. Reasons for not wanting to } \\
\text { know results included: wanting to remain hopeful; } \\
\text { avoiding potential family distress if testing positive; } \\
\text { and concerns about feeling guilty if testing negative. }\end{array}$ \\
\hline $\begin{array}{l}\text { Foley et al. } 2014 \text { (61) } \\
\text { Foley et al. } 2016(8)\end{array}$ & $n=34 \mathrm{ALS}$ patients & $\begin{array}{l}\text { Irish ALS-population- } \\
\text { based register }\end{array}$ & $\begin{array}{l}\text { Qualitative; unstructured } \\
\text { interviews }\end{array}$ & $\begin{array}{l}\text { To identify key psycho-social processes } \\
\text { that underpin ALS patient engagement } \\
\text { with healthcare services }\end{array}$ & $\begin{array}{l}\text { Family was the primary context to how patients } \\
\text { engaged with services and their decisions about care } \\
\text { were shaped by parenthood at different life stages. } \\
\text { Patients' strong sense of obligation to family and their } \\
\text { concern about family members shaped their } \\
\text { expressed preferences for care and the decisions they } \\
\text { made about care. Patients valued support from family } \\
\text { but struggled with becoming a burden on their family. } \\
\text { Patients' decisions pertaining to care were influenced } \\
\text { by their wish to alleviate distress for the wider family. }\end{array}$ \\
\hline Goy et al. 2008 (30) & $\begin{array}{l}n=50 \text { bereaved family } \\
\text { caregivers (ALS) } \\
n=54 \text { bereaved family } \\
\text { caregivers (other diagnoses) }\end{array}$ & $\begin{array}{l}\text { Health Science } \\
\text { University and } \\
\text { Movement Disorder } \\
\text { clinic, Portland, USA }\end{array}$ & $\begin{array}{l}\text { Quantitative; survey } \\
\text { questionnaire on end-of-life } \\
\text { care for deceased ALS } \\
\text { patients }\end{array}$ & $\begin{array}{l}\text { To compare ALS patients' palliative care } \\
\text { needs with the palliative care needs of } \\
\text { patients with Parkinson's Disease and } \\
\text { Parkinson's Related Disorders }\end{array}$ & $\begin{array}{l}\text { Family caregivers in ALS were more aware of patients' } \\
\text { choices for end-of-life care when compared to family } \\
\text { caregivers in PD and related disorders (PDRD). In the } \\
\text { views of family caregivers, suffering associated with } \\
\text { ALS is more severe than the suffering associated with } \\
\text { PDRD. }\end{array}$ \\
\hline $\begin{array}{l}\text { Greenaway et al. } 2015 \\
\text { (22) }\end{array}$ & $\begin{array}{l}n=21 \text { ALS patients } \\
n=12 \text { family caregivers [diad] }\end{array}$ & $\begin{array}{l}\text { South-East ALS } \\
\text { population-based } \\
\text { register, UK }\end{array}$ & $\begin{array}{l}\text { Qualitative; semi-structured } \\
\text { interviews }\end{array}$ & $\begin{array}{l}\text { To identify factors associated with } \\
\text { decisions made by ALS patients to accept } \\
\text { or decline non-invasive ventilation and/or } \\
\text { gastrostomy }\end{array}$ & $\begin{array}{l}\text { Patients' perceptions surrounding control and } \\
\text { acceptance impacted on their decisions to accept or } \\
\text { decline interventions. } \\
\text { Patients who had support from family were more } \\
\text { likely to accept interventions. Patients perceived that } \\
\text { family enabled them to share the burden of decision } \\
\text { making. } \\
\text { In some instances, patients perceived that family } \\
\text { members paid more attention to their own needs } \\
\text { than to the patient's needs when deciding about } \\
\text { interventions. }\end{array}$ \\
\hline Hartzfeld et al. 2015 (40) & $\begin{array}{l}n=10 \text { family members at } \\
50 \% \text { risk for familial ALS }\end{array}$ & $\begin{array}{l}\text { Neurologic Diseases } \\
\text { Registry, } \\
\text { Northwestern } \\
\text { University, Illinois, USA }\end{array}$ & $\begin{array}{l}\text { Qualitative; semi-structured } \\
\text { interviews }\end{array}$ & $\begin{array}{l}\text { To explore the reproductive decision- } \\
\text { making in individuals at } 50 \% \text { risk of } \\
\text { developing familial ALS from families with } \\
\text { a known genetic mutation }\end{array}$ & $\begin{array}{l}\text { Family members considered different reproductive } \\
\text { options (e.g. adoption, pre-implantation genetic } \\
\text { counselling). }\end{array}$ \\
\hline
\end{tabular}




\begin{tabular}{|c|c|c|c|c|c|}
\hline & & & & & $\begin{array}{l}\text { Participants who chose not to have children had more } \\
\text { direct exposure to ALS and of caring for a family } \\
\text { member with ALS when compared to participants } \\
\text { who chose to have children. } \\
\text { Children experiencing death of a parent was a primary } \\
\text { concern for all participants in the decision-making } \\
\text { process. }\end{array}$ \\
\hline Henschke 2012 (50) & $\begin{array}{l}n=19 \text { ALS patients } \\
n=14 \text { patients (other } \\
\text { diagnosis) } \\
n=\text { ? family members } 2\end{array}$ & $\begin{array}{l}\text { Non-profit association } \\
\text { register for rare } \\
\text { diseases, Germany }\end{array}$ & $\begin{array}{l}\text { Qualitative; semi-structured } \\
\text { interviews }\end{array}$ & $\begin{array}{l}\text { To explore ALS patients' and Duchenne } \\
\text { muscular dystrophy patients' problems } \\
\text { with the provision and financing of } \\
\text { assistive technology }\end{array}$ & $\begin{array}{l}\text { Patients and their family members encountered } \\
\text { problems accessing and financing assistive technology } \\
\text { devices and actively requested additional services } \\
\text { from service providers. }\end{array}$ \\
\hline $\begin{array}{l}\text { Hirano \& Yamazaki } 2010 \\
\text { (28) }\end{array}$ & $n=50$ ALS patients & $\begin{array}{l}\text { Japanese ALS } \\
\text { Association register }\end{array}$ & $\begin{array}{l}\text { Mixed methods; semi- } \\
\text { structured interviews, } \\
\text { multiple health and } \\
\text { psychological measures }\end{array}$ & $\begin{array}{l}\text { To examine decision-making for ALS } \\
\text { patients in invasive ventilation }\end{array}$ & $\begin{array}{l}\text { Patients feared becoming a burden on their family (by } \\
\text { choosing ventilation) but also desired to live in on } \\
\text { (with ventilation) to see their children and } \\
\text { grandchildren grow up. Some participants chose } \\
\text { ventilation to accommodate family members' hopes } \\
\text { and wishes. } \\
\text { A small number of participants had been ventilated on } \\
\text { the request of their family members when they went } \\
\text { into respiratory distress and without having made a } \\
\text { definite decision about invasive ventilation. }\end{array}$ \\
\hline $\begin{array}{l}\text { Hogden et al. } 2012 \text { (62) } \\
\text { Hogden et al. } 2013 \text { (63) } \\
\text { Hogden et al. } 2015 \text { (64) }\end{array}$ & $\begin{array}{l}n=14 \text { ALS patients } \\
n=8 \text { family caregivers [diad] } \\
n=32 \text { healthcare } \\
\text { professionals }\end{array}$ & $\begin{array}{l}\text { Two ALS clinics, South- } \\
\text { eastern Australia }\end{array}$ & $\begin{array}{l}\text { Qualitative; semi-structured } \\
\text { interviews }\end{array}$ & $\begin{array}{l}\text { To identify factors influencing ALS patient } \\
\text { decision-making in specialised } \\
\text { multidisciplinary care } \\
\text { To explore caregiver participation in } \\
\text { decision-making for ALS multidisciplinary } \\
\text { care } \\
\text { To examine how effective and patient- } \\
\text { centered decision making can be enacted } \\
\text { in ALS multidisciplinary care }\end{array}$ & $\begin{array}{l}\text { Family caregivers strove to promote the patient voice } \\
\text { in decision-making and they actively assisted patients } \\
\text { in multiple aspects of care (e.g. enabled patient health } \\
\text { literacy, sourced information for the patient, provided } \\
\text { information to HCPs on behalf of patient, provided } \\
\text { emotional support to patient and assisted in } \\
\text { coordinating patient care). } \\
\text { Patients did not want to burden their families but } \\
\text { family relationships motivated patients to engage } \\
\text { with interventions that could prolong their lives. Some } \\
\text { patients framed survival around children milestones. } \\
\text { Most patients wanted to share decision-making with } \\
\text { family and healthcare professionals. }\end{array}$ \\
\hline $\begin{array}{l}\text { Hyunjin \& Schepp } 2013 \\
\text { (53) }\end{array}$ & $n=11$ family caregivers & $\begin{array}{l}\text { Metropolitan area, } \\
\text { South Korea }\end{array}$ & $\begin{array}{l}\text { Qualitative; semi-structured } \\
\text { interviews and observation }\end{array}$ & $\begin{array}{l}\text { To describe the lived experience of } \\
\text { spouses of ALS patients }\end{array}$ & $\begin{array}{l}\text { Family caregivers' (wives) felt burdened by their new } \\
\text { roles as decision-maker for the family and by the need } \\
\text { to make decisions about care for the patient. }\end{array}$ \\
\hline
\end{tabular}




\begin{tabular}{|c|c|c|c|c|c|}
\hline Kurisaki et al. 2014 (27) & $n=29$ ALS patients & $\begin{array}{l}\text { Neurology centre, } \\
\text { Kumamoto University } \\
\text { Hospital, Japan }\end{array}$ & $\begin{array}{l}\text { Quantitative; retrospective } \\
\text { analysis of patients' clinical } \\
\text { characteristics and patients' } \\
\text { stated preferences for care }\end{array}$ & $\begin{array}{l}\text { To evaluate the decision-making process } \\
\text { of non-invasive ventilated ALS patients for } \\
\text { invasive ventilation in the future }\end{array}$ & $\begin{array}{l}\text { The use of non-invasive ventilation was an important } \\
\text { factor in patients' decision to move to invasive } \\
\text { ventilation. } \\
\text { Some patients accepted invasive ventilation so that } \\
\text { they would remain alive for family events. No } \\
\text { differences in family structure existed between the } \\
\text { patients who opted for invasive ventilation and those } \\
\text { who did not. }\end{array}$ \\
\hline Larsson et al. 2015 (57) & $\begin{array}{l}n=15 \text { bereaved relatives } \\
\text { (including } n=13 \text { bereaved } \\
\text { family caregivers) }\end{array}$ & $\begin{array}{l}\text { Two ALS clinics, } \\
\text { Sweden }\end{array}$ & $\begin{array}{l}\text { Qualitative; semi-structured } \\
\text { interviews }\end{array}$ & $\begin{array}{l}\text { To describe relatives' experiences of ALS } \\
\text { patient care and of the support they } \\
\text { received during the course of disease } \\
\text { progression }\end{array}$ & $\begin{array}{l}\text { Family caregivers/relatives reported that they focused } \\
\text { more on the patient's needs than their own. They } \\
\text { requested that support from services be prioritised } \\
\text { based on the patient's needs versus the caregiver's } \\
\text { needs. }\end{array}$ \\
\hline $\begin{array}{l}\text { Lemoignan \& Ells } 2010 \\
\text { (25) }\end{array}$ & $\begin{array}{l}n=9 \text { ALS patients } \\
n=? \text { family caregivers }{ }^{3}[\mathrm{diad}]\end{array}$ & $\begin{array}{l}\text { ALS clinic, Montreal, } \\
\text { Canada }\end{array}$ & $\begin{array}{l}\text { Qualitative; semi-structured } \\
\text { interviews }\end{array}$ & $\begin{array}{l}\text { To explore the decision-making process in } \\
\text { assisted ventilation for ALS patients }\end{array}$ & $\begin{array}{l}\text { Contextual factors including functional status, support } \\
\text { from services and relationship with family shaped } \\
\text { patients' decision-making. Patients were keen to } \\
\text { minimise family caregiver burden despite their } \\
\text { dependence on family. } \\
\text { Patients and family caregivers could differ in their } \\
\text { preferences for care but family caregivers respected } \\
\text { patient wishes and advocated on behalf of the } \\
\text { patient. }\end{array}$ \\
\hline Lerum et al. 2016 (55) & $\begin{array}{l}n=25 \text { family caregivers } \\
\text { (including } n=8 \text { bereaved } \\
\text { family caregivers) }\end{array}$ & $\begin{array}{l}\text { Three ALS clinics, } \\
\text { Norway }\end{array}$ & $\begin{array}{l}\text { Qualitative; narrative and } \\
\text { semi-structured interviews }\end{array}$ & $\begin{array}{l}\text { To explore family caregivers' perceptions } \\
\text { of their responsibilities in caring for a } \\
\text { person with ALS }\end{array}$ & $\begin{array}{l}\text { Family caregivers reported strong commitment to } \\
\text { caring for the person with ALS and they strove to } \\
\text { manage competing family obligations. They chose to } \\
\text { engage with available support services to assist them } \\
\text { in their caring role. }\end{array}$ \\
\hline Maessen et al. 2009 (17) & $\begin{array}{l}n=198 \text { bereaved caregivers } \\
\text { (approx. } 93 \% \text { bereaved } \\
\text { family caregivers) } \\
n=204 \text { physicians }\end{array}$ & $\begin{array}{l}\text { National ALS clinic, } \\
\text { Utrecht, Netherlands }\end{array}$ & $\begin{array}{l}\text { Quantitative; cohort survey: } \\
\text { questionnaires on end-of-life } \\
\text { care }\end{array}$ & $\begin{array}{l}\text { To determine factors that influence end- } \\
\text { of-life practices in ALS }\end{array}$ & $\begin{array}{l}\text { Patients' decisions to undergo euthanasia or } \\
\text { physician-assisted suicide was significantly associated } \\
\text { with being more educated and with dying at home } \\
\text { with support of family. } \\
\text { Patients' decisions to undergo euthanasia and } \\
\text { physician-assisted suicide were not associated with } \\
\text { quality of care or patient depression. Loss of dignity, } \\
\text { being dependent on others, illness progression and } \\
\text { fear of choking were reasons for patients shortening } \\
\text { life. }\end{array}$ \\
\hline Mannino et al. 2007 (49) & $\begin{array}{l}n=30 \text { ALS patients } \\
n=30 \text { caregivers [diad] }\end{array}$ & $\begin{array}{l}\text { ALS clinic, Palermo, } \\
\text { Italy }\end{array}$ & $\begin{array}{l}\text { Mixed methods; patient } \\
\text { functional rating scale } \\
\text { (completed separately by } \\
\text { patients and family } \\
\text { caregivers } n=30 \text { [diad]), } \\
\text { unstructured interviews (with }\end{array}$ & $\begin{array}{l}\text { To capture ALS patients' and/or family } \\
\text { caregivers' perspective on patients' (in } \\
\text { advanced stages of ALS) health status }\end{array}$ & $\begin{array}{l}\text { Both patients and family caregivers asked for more } \\
\text { assistive and adaptive equipment than they had } \\
\text { received. Most frequently reported patient symptoms } \\
\text { included declining strength and swallow and } \\
\text { respiratory problems. Patients' and their family }\end{array}$ \\
\hline
\end{tabular}




\begin{tabular}{|c|c|c|c|c|c|}
\hline & $\begin{array}{l}n=16 \text { ALS patients } \\
n=6 \text { family caregivers [diad] }\end{array}$ & & $\begin{array}{l}\text { patients and family } \\
\text { caregivers) }\end{array}$ & $\begin{array}{l}\text { To identify current care needs of ALS } \\
\text { patients }\end{array}$ & $\begin{array}{l}\text { caregivers' views on patient functional status } \\
\text { correlated highly. }\end{array}$ \\
\hline Martin et al. 2014 (16) & $\begin{array}{l}n=78 \text { ALS patients } \\
n=50 \text { caregivers [diad] } \\
\text { (including } 49 \text { family } \\
\text { caregivers) }\end{array}$ & $\begin{array}{l}\text { South-East ALS } \\
\text { population-based } \\
\text { register, UK }\end{array}$ & $\begin{array}{l}\text { Quantitative; longitudinal } \\
\text { prospective: } \\
\text { ALS functional rating scales, } \\
\text { cognitive / behavioural } \\
\text { measures [including the } \\
\text { Frontal Systems Behavior } \\
\text { Scale], psychological-based } \\
\text { measures, and Palliative Care } \\
\text { Outcome Scale (patient } \\
\text { version) } \\
\text { Health and psychological- } \\
\text { based measures (for } \\
\text { caregivers) } \\
\text { Palliative Care Outcome Scale } \\
\text { (caregiver version) }\end{array}$ & $\begin{array}{l}\text { To identify factors associated with } \\
\text { acceptance of non-invasive ventilation } \\
\text { and gastrostomy in ALS }\end{array}$ & $\begin{array}{l}\text { Family caregivers' ratings on good palliative care } \\
\text { outcomes were associated with patient refusal of } \\
\text { gastrostomy and non-invasive ventilation. Post- } \\
\text { decision - patients who refused interventions were } \\
\text { more likely to be patients with a worse caregiver- } \\
\text { related palliative outcome. } \\
\text { Caregivers with better general psychological wellbeing } \\
\text { and lower caregiver strain at time of decision making } \\
\text { were more likely to be caregivers of patients who } \\
\text { refused interventions. } \\
\text { Educational status, IQ and executive dysfunction of } \\
\text { patients were associated with acceptance or refusal of } \\
\text { interventions. } \\
\text { Patients' understanding of their illness and their early } \\
\text { approach to considering interventions were } \\
\text { associated with treatment decisions. }\end{array}$ \\
\hline McKim et al. 2012 (29) & $\begin{array}{l}n=26 \text { ALS patients } \\
n=26 \text { family caregivers [diad] }\end{array}$ & $\begin{array}{l}\text { Respiratory } \\
\text { rehabilitation centre, } \\
\text { Ottawa, Canada }\end{array}$ & $\begin{array}{l}\text { Quantitative; longitudinal } \\
\text { prospective: ventilation } \\
\text { choice questionnaires and } \\
\text { psychological measure of } \\
\text { emotional wellbeing }\end{array}$ & $\begin{array}{l}\text { To evaluate an education programme on } \\
\text { invasive ventilation for ALS patients and } \\
\text { their family caregivers } \\
\text { To determine whether patients' choices } \\
\text { of ventilator support after the education } \\
\text { programme predicted patients' real life } \\
\text { choices of ventilator support }\end{array}$ & $\begin{array}{l}\text { Patients were less anxious than family caregivers } \\
\text { about the prospect of having to make a decision } \\
\text { about future ventilation. } \\
\text { Patients' choices of ventilator support following } \\
\text { education about ventilation predicted real-life choices } \\
\text { in } 78 \% \text { of cases. }\end{array}$ \\
\hline Morris et al. 2013 (52) & $\begin{array}{l}n=3 \text { ALS patients } \\
n=9 \text { patients (other } \\
\text { diagnoses) }\end{array}$ & Pacific Northwest, USA & $\begin{array}{l}\text { Qualitative; semi-structured } \\
\text { interviews and online focus } \\
\text { group }\end{array}$ & $\begin{array}{l}\text { To explore the experiences of AAC users } \\
\text { when communicating with medical } \\
\text { providers }\end{array}$ & $\begin{array}{l}\text { AAC users encountered multiple problems in } \\
\text { communicating with service providers. AAC users } \\
\text { were dependent on their caregiver/family members } \\
\text { to co-ordinate care, serve as an interpreter and to } \\
\text { actively participate in decision-making in the clinical } \\
\text { encounter. Participants felt responsible to consider all } \\
\text { members of family in their decisions pertaining to } \\
\text { care. }\end{array}$ \\
\hline Murray et al. 2016 (34) & $\begin{array}{l}n=18 \text { bereaved family } \\
\text { caregivers }\end{array}$ & $\begin{array}{l}\text { Specialist } \\
\text { rehabilitation and } \\
\text { palliative care } \\
\text { hospital, Sydney, } \\
\text { Australia }\end{array}$ & $\begin{array}{l}\text { Qualitative; semi-structured } \\
\text { interviews }\end{array}$ & $\begin{array}{l}\text { To investigate ALS caregivers' } \\
\text { perspectives on the accessibility and } \\
\text { impact of advance care planning for ALS } \\
\text { patients and their caregivers }\end{array}$ & $\begin{array}{l}\text { Family caregivers indicated that advance care } \\
\text { planning documented in a letter format can increase } \\
\text { patient autonomy, ease the difficulty surrounding } \\
\text { end-of-life care decision-making for patients, give } \\
\text { clarity to patients' wishes and enhance } \\
\text { communication among the wider family. }\end{array}$ \\
\hline
\end{tabular}




\begin{tabular}{|c|c|c|c|c|c|}
\hline & & & & & $\begin{array}{l}\text { Patients' and their family caregivers' acceptance of } \\
\text { the impending death influenced when patients and } \\
\text { family caregivers engaged with advance directives. }\end{array}$ \\
\hline Nolan et al. 2008 (36) & $\begin{array}{l}n=16 \text { ALS patients } \\
n=16 \text { family members [diad] }\end{array}$ & $\begin{array}{l}\text { Specialised teaching } \\
\text { hospital, Baltimore, } \\
\text { USA }\end{array}$ & $\begin{array}{l}\text { Mixed methods; patient } \\
\text { control preference scale for } \\
\text { family involvement, family } \\
\text { member decision-making } \\
\text { survey, semi-structured } \\
\text { interviews ( } 5 \text { family members } \\
\text { after patient death). } \\
\text { Patient cognitive status screened: } \\
\text { - Mental status questionnaire } \\
\text { - Confusion assessment method }\end{array}$ & $\begin{array}{l}\text { To compare ALS patients' preferences for } \\
\text { involving family in the decision making } \\
\text { process at end-of-life care and the actual } \\
\text { involvement by family at time of death }\end{array}$ & $\begin{array}{l}\text { Patients who opted to make decisions independently } \\
\text { were more likely to have family report that decisions } \\
\text { were made in the style preferred by patient. } \\
\text { Patients who preferred shared decision-making with } \\
\text { family or decision-making that relied on family were } \\
\text { more likely to have family report that decisions were } \\
\text { made more independent of the style preferred by } \\
\text { patient. }\end{array}$ \\
\hline Nolan et al. 2009 (39) & $\begin{array}{l}n=24 \text { family members (ALS) } \\
n=24 \text { family members (other } \\
\text { diagnoses) }\end{array}$ & $\begin{array}{l}\text { Specialised teaching } \\
\text { hospital, Baltimore, } \\
\text { USA }\end{array}$ & $\begin{array}{l}\text { Mixed methods; structured } \\
\text { interviews with family } \\
\text { members, testing of a Family } \\
\text { Member Decision-Making } \\
\text { Self-Efficacy scale }\end{array}$ & $\begin{array}{l}\text { To develop and validate a Decision- } \\
\text { making Self-Efficacy Scale for Family } \\
\text { members }\end{array}$ & $\begin{array}{l}\text { Family members who had experience of making } \\
\text { decisions for an ill family member had higher levels of } \\
\text { decision making self-efficacy compared to those } \\
\text { without the experience. }\end{array}$ \\
\hline $\begin{array}{l}\text { O'Brien et al. } 2011 \text { (44) } \\
\text { O'Brien et al. } 2011 \text { (47) } \\
\text { O'Brien et al. } 2012 \text { (45) } \\
\text { Whitehead et al. } 2012 \\
\text { (33) }\end{array}$ & $\begin{array}{l}n=24 \text { ALS patients } \\
n=18 \text { family caregivers [17 } \\
\text { diad] } \\
n=10 \text { bereaved family } \\
\text { caregivers }\end{array}$ & ALS clinic, Preston, UK & $\begin{array}{l}\text { Qualitative; narrative } \\
\text { interviews }\end{array}$ & $\begin{array}{l}\text { To explore ALS patients' and caregivers' } \\
\text { experiences of care between symptom } \\
\text { onset and diagnosis } \\
\text { To explore the views of ALS patients and } \\
\text { their caregivers regarding } \\
\text { multidisciplinary care in ALS } \\
\text { To explore ALS caregivers' need for and } \\
\text { use of support services in ALS } \\
\text { To explore ALS patients' and their } \\
\text { caregivers' experiences of death, dying } \\
\text { and bereavement in ALS }\end{array}$ & $\begin{array}{l}\text { Patients' impetus to seek medical advice resulted } \\
\text { from worsening symptoms. Some patients took a } \\
\text { proactive approach to obtain a specialist opinion } \\
\text { when general practitioners failed to recognise } \\
\text { symptoms. Immediate post-diagnostic support was } \\
\text { important for patients. } \\
\text { Family caregivers recognised the need for more } \\
\text { information, home care, respite care, counselling and } \\
\text { training in the physical caring for the patient. } \\
\text { Family caregiver burden was excessive and in some } \\
\text { cases exacerbated patient distress and desire for } \\
\text { hastening death. Patients expressed the wish to die at } \\
\text { home. } \\
\text { Advance care planning was regarded as beneficial by } \\
\text { both patients and family caregivers to increase } \\
\text { patient autonomy and awareness of patient } \\
\text { preferences. }\end{array}$ \\
\hline O'Brien et al. 2012 (46) & $\begin{array}{l}n=24 \text { ALS patients } \\
n=18 \text { family caregivers }[17 \\
\text { diad] }\end{array}$ & ALS clinic, Preston, UK & $\begin{array}{l}\text { Mixed methods; narrative } \\
\text { interviews, health status } \\
\text { measure \& functional rating } \\
\text { scale for patient, case/clinical } \\
\text { notes }\end{array}$ & $\begin{array}{l}\text { To identify factors related to uptake of } \\
\text { social services homecare in ALS }\end{array}$ & $\begin{array}{l}\text { Patients' and family caregivers' desire to maintain } \\
\text { control and normality and their uncertainty } \\
\text { surrounding entitlement to services delayed their } \\
\text { uptake of services. }\end{array}$ \\
\hline
\end{tabular}




\begin{tabular}{|c|c|c|c|c|c|}
\hline Ozanne et al. 2015 (43) & $n=13$ family caregivers & ALS clinic, Sweden & $\begin{array}{l}\text { Qualitative; semi-structured } \\
\text { interviews }\end{array}$ & $\begin{array}{l}\text { To explore how spouses of ALS patients } \\
\text { find meaning in life }\end{array}$ & $\begin{array}{l}\text { Distress about the prognosis in ALS made some family } \\
\text { caregivers reluctant to seek support from healthcare } \\
\text { services. Family caregivers' reported prioritising } \\
\text { patients' needs over their own needs. }\end{array}$ \\
\hline Preston et al. 2012 (35) & $\begin{array}{l}n=11 \text { bereaved relatives or } \\
\text { bereaved primary family } \\
\text { caregivers }\end{array}$ & ALS clinic, Preston, UK & $\begin{array}{l}\text { Qualitative; semi-structured } \\
\text { interviews }\end{array}$ & $\begin{array}{l}\text { To examine ALS bereaved relatives' or } \\
\text { family caregivers' experiences of using the } \\
\text { Preferred Priorities for Care (PPC) } \\
\text { Document and their perceptions about its } \\
\text { impact on end-of-life care }\end{array}$ & $\begin{array}{l}\text { Most participants felt that the PPC should be } \\
\text { completed when patients are still able to } \\
\text { communicate. All but two patients completed the PCC } \\
\text { in the presence of a relative. } \\
\text { Relatives' perceived benefits of advance directives } \\
\text { included: increased patient autonomy; reducing } \\
\text { patient anxiety in relation to end-of-life care } \\
\text { decisions; and the potential to increase HCPs' } \\
\text { awareness of patients' wishes. }\end{array}$ \\
\hline Rabkin et al. 2014 (15) & $\begin{array}{l}n=224 \text { ALS patients } \\
n=217 \text { family caregivers } \\
\text { [diad] }\end{array}$ & $\begin{array}{l}\text { Five ALS clinics in USA } \\
\text { and six ALS clinics in } \\
\text { Japan }\end{array}$ & $\begin{array}{l}\text { Quantitative; cross-national } \\
\text { survey: questionnaire }\end{array}$ & $\begin{array}{l}\text { To elicit American and Japanese ALS } \\
\text { patients' and their family caregivers' } \\
\text { preferences regarding invasive ventilation }\end{array}$ & $\begin{array}{l}\text { Most patients ( } 80 \% \text { ) with advanced respiratory } \\
\text { impairment were undecided about or opposed to } \\
\text { invasive ventilation. } \\
\text { In both US and Japan - more family caregivers than } \\
\text { patients favoured invasive ventilation. Japanese } \\
\text { family caregivers were significantly more in favour of } \\
\text { invasive ventilation than were Japanese patients. }\end{array}$ \\
\hline $\begin{array}{l}\text { Ray \& Street } 2007 \text { (58) } \\
\text { Ray \& Street } 2011 \text { (59) }\end{array}$ & $\begin{array}{l}n=24 \text { caregivers (including } \\
n=22 \text { family caregivers and } \\
n=2 \text { non-family caregivers); } \\
\text { including } n=18 \text { primary } \\
\text { caregivers and } n=6 \\
\text { peripheral caregivers }\end{array}$ & $\begin{array}{l}\text { MND Association, } \\
\text { Victoria, Australia }\end{array}$ & $\begin{array}{l}\text { Qualitative longitudinal; } \\
\text { semi-structured interviews }\end{array}$ & $\begin{array}{l}\text { To explore the losses and emotional } \\
\text { distress encountered by caregivers of } \\
\text { people with ALS } \\
\text { To investigate the processes that } \\
\text { underpin relationships in supportive } \\
\text { networks among ALS caregivers }\end{array}$ & $\begin{array}{l}\text { Caregivers encountered substantial psychosocial and } \\
\text { emotional loss in their caring roles. Despite perceived } \\
\text { change in their relationship with the person with ALS, } \\
\text { caregivers remained committed in their caring role. }\end{array}$ \\
\hline Rosengren et al. 2015 (60) & $n=4 \mathrm{ALS}$ patients & $\begin{array}{l}\text { Google search of ALS } \\
\text { biographies }\end{array}$ & $\begin{array}{l}\text { Qualitative; analysis of ALS } \\
\text { biographies }\end{array}$ & $\begin{array}{l}\text { To describe ALS patients' experiences of } \\
\text { living with ALS at the end-of-life }\end{array}$ & $\begin{array}{l}\text { Participants encountered suffering in everyday life. } \\
\text { They considered ending their lives but chose to live on } \\
\text { with ALS, in part, because they valued the emotional } \\
\text { support rendered to them by their family. }\end{array}$ \\
\hline Sharma et al. 2011 (38) & $\begin{array}{l}n=27 \text { ALS patients } \\
n=27 \text { family members [diad] } \\
n=25 \text { patients (other } \\
\text { diagnosis) with } n=25 \text { family } \\
\text { members [diad] }\end{array}$ & $\begin{array}{l}\text { Specialised teaching } \\
\text { hospital, Baltimore, } \\
\text { USA }\end{array}$ & $\begin{array}{l}\text { Quantitative; cross-sectional } \\
\text { survey: patient-family } \\
\text { decision-making scale, } \\
\text { patient functional rating } \\
\text { scales } \\
\text { Patient cognitive status screened: } \\
\text { - Mental status questionnaire }\end{array}$ & $\begin{array}{l}\text { To evaluate the ability of family members } \\
\text { to correctly identify patients' preferences } \\
\text { for family involvement in decision making }\end{array}$ & $\begin{array}{l}\text { Family members were often unable to correctly } \\
\text { identify patient preferences for family involvement in } \\
\text { end-of-life care decision-making - particularly in cases } \\
\text { where patients desired that family decide about care } \\
\text { in the event of patient decisional incapacity. }\end{array}$ \\
\hline $\begin{array}{l}\text { Stavroulakis et al. } 2014 \\
\text { (19) }\end{array}$ & $\begin{array}{l}n=10 \text { ALS patients } \\
n=8 \text { family caregivers }\end{array}$ & $\begin{array}{l}\text { ALS clinic, Sheffield, } \\
\text { UK }\end{array}$ & $\begin{array}{l}\text { Qualitative; semi-structured } \\
\text { interviews }\end{array}$ & $\begin{array}{l}\text { To explore ALS patients' and their } \\
\text { caregivers' perceptions of the benefits } \\
\text { and challenges of using gastrostomy }\end{array}$ & $\begin{array}{l}\text { Despite clinical, practical and psychological challenges } \\
\text { of using gastrostomy, patients and family caregivers } \\
\text { persevered with gastrostomy because of the benefits } \\
\text { it derived - nutritional benefit for patient and reduced }\end{array}$ \\
\hline
\end{tabular}




\begin{tabular}{|c|c|c|c|c|c|}
\hline $\begin{array}{l}\text { Stavroulakis et al. } 2016 \\
\text { (18) }\end{array}$ & [diad] & & & $\begin{array}{l}\text { To identify factors that influence ALS } \\
\text { patient and caregiver decision-making in } \\
\text { relation to the timing of gastrostomy } \\
\text { insertion }\end{array}$ & $\begin{array}{l}\text { anxiety (associated with mealtime) for both patient } \\
\text { and family caregivers. }\end{array}$ \\
\hline Sulmasy et al. 2007 (37) & $\begin{array}{l}n=32 \text { ALS patients } \\
n=115 \text { other diagnoses }\end{array}$ & $\begin{array}{l}\text { Two specialised } \\
\text { teaching hospitals: } \\
\text { Baltimore and New } \\
\text { York, USA }\end{array}$ & $\begin{array}{l}\text { Quantitative longitudinal } \\
\text { (prospective); patient control } \\
\text { preference scale for } \\
\text { family/physician } \\
\text { involvement, Qol and health } \\
\text { status measures } \\
\text { Patient cognitive status screened: } \\
\text { - Mental status questionnaire } \\
\text { - Confusion assessment method }\end{array}$ & $\begin{array}{l}\text { To determine the role terminally-ill } \\
\text { patients would opt to have their family } \\
\text { members and physicians play in decision } \\
\text { making should patients lose decision- } \\
\text { making capacity }\end{array}$ & $\begin{array}{l}\text { Patients varied in their control preferences but most } \\
\text { opted for shared decision-making with their loved } \\
\text { ones and with physicians. } \\
\text { Control preferences remained stable overtime with } \\
\text { respect to family but patients became somewhat less } \\
\text { reliant on physicians. }\end{array}$ \\
\hline Sundling et al. 2009 (24) & $\begin{array}{l}n=7 \text { ALS patients } \\
n=8 \text { family caregivers }(7 \\
\text { diad] }\end{array}$ & $\begin{array}{l}\text { University Hospital, } \\
\text { Huddinge, Sweden }\end{array}$ & $\begin{array}{l}\text { Qualitative; semi-structured } \\
\text { interviews }\end{array}$ & $\begin{array}{l}\text { To describe ALS patients' and their } \\
\text { caregivers' experiences of non-invasive } \\
\text { ventilation }\end{array}$ & $\begin{array}{l}\text { Patients agreed to home ventilation but also had } \\
\text { contradictory emotions because of their dependence } \\
\text { on it. } \\
\text { Patient perceived benefits of non-invasive ventilation } \\
\text { included better symptom management and the } \\
\text { opportunity to re-engage with family-related } \\
\text { activities. } \\
\text { Family caregivers chose to take on the burden of care } \\
\text { associated with non-invasive ventilation because of } \\
\text { the positive effects experienced by the person with } \\
\text { ALS. }\end{array}$ \\
\hline Tagami et al. 2014 (14) & $n=160$ ALS patients & $\begin{array}{l}\text { Neurology care facility, } \\
\text { Osaka, Japan }\end{array}$ & $\begin{array}{l}\text { Quantitative; retrospective } \\
\text { cohort study: documentation } \\
\text { of patient stated preferences, } \\
\text { clinical data and } \\
\text { interventions, functional } \\
\text { rating scale }\end{array}$ & $\begin{array}{l}\text { To evaluate factors related to ALS } \\
\text { patients' choices about invasive } \\
\text { ventilation }\end{array}$ & $\begin{array}{l}\text { Age, shorter duration from disease onset and the } \\
\text { presence of a spouse were independently associated } \\
\text { with patients' decisions to undergo invasive } \\
\text { ventilation. } \\
\text { Among patient }<65 \text { yrs at time of TIV, a higher } \\
\text { percentage of patients with a spouse underwent TIV } \\
\text { compared to patients without a spouse. }\end{array}$ \\
\hline Veronese et al. 2014 (23) & $\begin{array}{l}n=19 \text { bereaved family } \\
\text { caregivers }\end{array}$ & $\begin{array}{l}\text { Italian regional ALS } \\
\text { population-based } \\
\text { register }\end{array}$ & $\begin{array}{l}\text { Qualitative; semi-structured } \\
\text { interviews }\end{array}$ & $\begin{array}{l}\text { To explore ALS patients' final months of } \\
\text { life on invasive ventilation } \\
\text { To explore caregivers' experiences of care } \\
\text { during ALS patients' final months of life } \\
\text { on invasive ventilation }\end{array}$ & $\begin{array}{l}\text { The majority of patients had not wanted to be } \\
\text { tracheostomised before the procedure but often felt } \\
\text { pressurised by physicians to choose tracheostomy. } \\
\text { Family caregivers were sensitive to patients' } \\
\text { preferences. In some cases, family caregivers felt } \\
\text { pressurised by physicians to convince the patient to } \\
\text { agree to invasive ventilation. }\end{array}$ \\
\hline
\end{tabular}




\begin{tabular}{|l|l|l|l|l|l|}
\hline Wagner et al. 2016 (42) & $n=449$ ALS patients & $\begin{array}{l}\text { Centers for Disease } \\
\text { Control Agency for } \\
\text { Toxic Substances and } \\
\text { Disease Registry (CDC } \\
\text { ATSDR), USA }\end{array}$ & $\begin{array}{l}\text { Quantitative; national survey: } \\
\text { questionnaire }\end{array}$ & $\begin{array}{l}\text { To investigate ALS patients' interest in } \\
\text { and access to genetic testing }\end{array}$ & $\begin{array}{l}\text { Patients had a high interest in genetic testing. Patients } \\
\text { with a family history of ALS reported a more } \\
\text { favourable attitude towards genetic testing. The } \\
\text { majority of participants would support their adult } \\
\text { children to engage with genetic testing. }\end{array}$ \\
\hline
\end{tabular}

